\title{
A Review on Global E-Waste Management: Urban Mining towards a Sustainable Future and Circular Economy
}

\author{
Venkatesha Murthy ${ }^{1}$ and Seeram Ramakrishna ${ }^{2, *(D)}$ \\ 1 VANS Chemistry Pte Ltd., Singapore 658065, Singapore; venky@vanschemistry.com \\ 2 Department of Mechanical Engineering, College of Design and Engineering, National University of Singapore, \\ Singapore 117576, Singapore \\ * Correspondence: seeram@nus.edu.sg
}

Citation: Murthy, V.; Ramakrishna, S. A Review on Global E-Waste

Management: Urban Mining towards a Sustainable Future and Circular Economy. Sustainability 2022, 14, 647. https://doi.org/10.3390/su14020647

Academic Editor: Silvia Fiore

Received: 22 November 2021

Accepted: 29 December 2021

Published: 7 January 2022

Publisher's Note: MDPI stays neutral with regard to jurisdictional claims in published maps and institutional affiliations.

Copyright: (C) 2022 by the authors. Licensee MDPI, Basel, Switzerland. This article is an open access article distributed under the terms and conditions of the Creative Commons Attribution (CC BY) license (https:// creativecommons.org/licenses/by/ $4.0 /)$.

\begin{abstract}
The trending need for smarter electrical and electronic equipment (EEE) is surging globally by the year and is giving rise to huge amounts of outdated EEE going into landfills. This has caused enormous threats to our environment and the health of living beings due to its unsustainable ways of collection, treatment and disposal of waste EEE or E-waste. With increasing E-waste, the formal sectors lack infrastructure, technology and expertise required to collect and process the E-waste in an environmentally sound manner. This article is intended to bring out the global best practices in the field of E-waste management, to shed light on the importance of policy implementation, technology requirement and social awareness to arrive at a sustainable and circular economy. Although about $71 \%$ of the world's populace has incorporated E-waste legislation, there is a need to enforce and implement a common legal framework across the globe. The article explains the gap created among the stakeholders and their knowledge on the roles and responsibilities towards a legalized E-waste management. It further explains the lack of awareness on extended producer responsibility (EPR) and producer responsibility schemes. Despite various legislations in force, numerous illegal practices such as acid leaching, open incineration, illegal dumping carried out by the informal sector are causing harm to the environment, natural resources and the safety of unorganized and unskilled labor. The article discusses the crucial need for awareness amongst stakeholders, consumer behavior and the global challenges and opportunities in this field to achieve a low-carbon, circular economy. To conclude, the article highlights the importance of common legal framework, EPR and licenses, transformation of the informal sector, benchmark technologies, responsibilities of various stakeholders and entrepreneurial opportunities to enhance the formal capacity. The article wholly advocates for transparency, accountability and traceability in the E-waste recycling chain, thus creating a greener environment and protecting our planet and natural resources for future generations.
\end{abstract}

Keywords: E-waste; circular economy; informal sector; legislation; E-waste management; decarbonization; extended producer responsibility; producer responsibility organization; waste electrical and electronic equipment; sustainability

\section{Introduction}

Electrical and electronic equipment (EEE) has turned out to be the most vital accessory to our everyday life. The easy accessibility and predominant use have enabled most of us across the globe to live a higher standard of lifestyle. Nevertheless, the way in which we manufacture, use and discard E-waste is unsustainable and unacceptable. As per the recent reports by the United Nations (UN), in 2021, on an average, each person is expected to generate about 7.6 [1] kg per capita of E-waste, resulting in a massive amount of 57.4 [1] MMT across the globe [1].

The COVID-19 pandemic had an explicit effect on our use of electronics and digital solutions, with people relying on electronics to keep them connected with co-workers, healthcare professionals, family and social life. Children using smartphones for online 
education has had its own pros and cons. On the one hand, they are able to access progressive learning, and on the other hand, they are exposed to the trends of social media and online gaming and its ill effects [2-4]. The European Union stated that, as per a survey commissioned by the European Parliament, the demand for personal computers and tablets rose by $4.6 \%$ year-on-year [5]. The combined effect of the pandemic and the drastic shift towards the prolonged use of artificial intelligence (AI) resulted in privacy infringements, lack of physical activity, health concerns and lack of social interactions.

\section{Global E-Waste Statistics and Value}

In accordance with the global E-waste studies, in 2019, the world generated 53.6 Mt of E-waste which was an alarming $21 \%$ increase in the last 5 years. The reports also predicted that the generation of E-waste will reach 74 [6] Mt globally, within a short period, i.e., by 2030. This is almost double the amount in 16 years from 2014 [7]. In proportion to this data, E-waste becomes the rapidly growing domestic waste stream across the globe. This is mainly due to shorter life cycles, frequent changes in technology, shorter life spans, changes in consumer behavior and limited options of repair for EEE. In the year 2019 (Figures 1 and 2), statistics showed that Asia topped in the generation of E-waste, with 24.9 [6] Mt, accompanied by the Americas with 13.1 [6] Mt, Europe with 12 [6] Mt and, lastly, Africa and Oceania with 2.9 [6] Mt and 0.7 [6] Mt, respectively [7].

Only $17.4 \%$ [6] (9.3 Mt) of E-waste was collected and accounted for, whereas $82.6 \%$ (44.3 Mt) [6] was speculative and its environmental and human health impact varied across the globe. E-waste is an untreated treasure and it may contain variety of natural and processed resources such as precious and platinum group metals, base metals, plastics and other non-metals. These metals are valued at around USD 65 billion which is more or less the gross domestic product (GDP) of majority of the countries. These valuables were either openly dumped or incinerated instead of processing at formal facilities to extend the life of resources by recovering them as secondary raw materials [8].
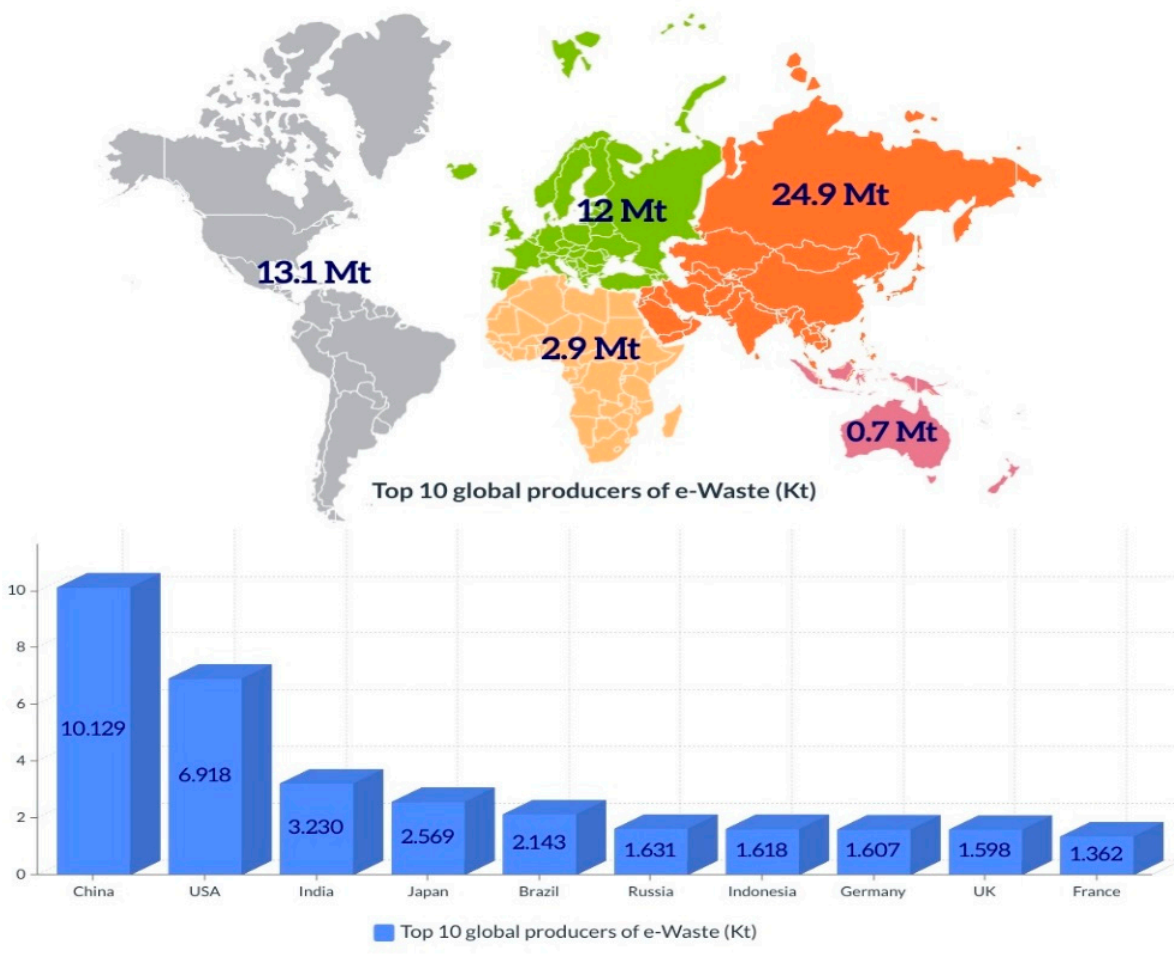

Figure 1. Statistics on the biggest global producers of E-waste. 


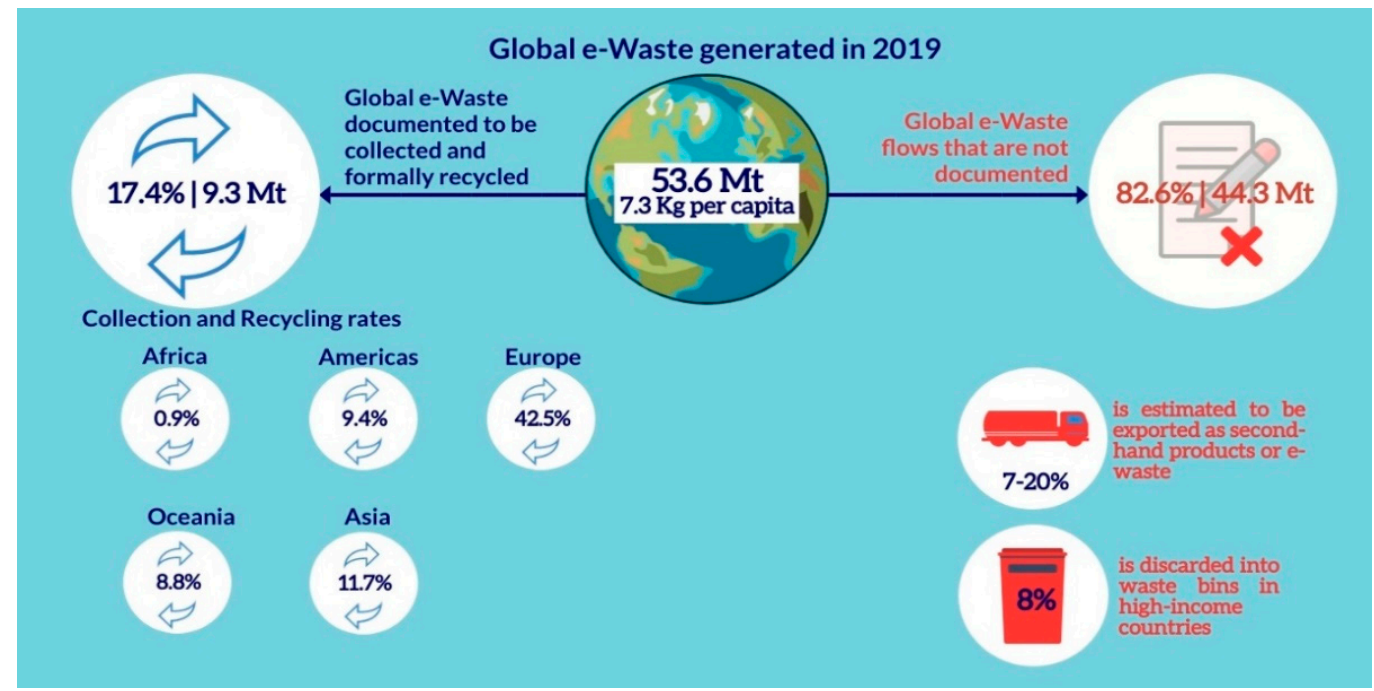

Figure 2. Statistics on the amount of E-waste processed formally and informally across the globe [7] (Source: Forti et al., 2020).

\section{The World Health Organization (WHO) Report 2021: Children and Digital Dumpsites}

In accordance with the first report released by the WHO on E-waste, it is observed that around 12.9 [9] million women who work for the informal sector are conceivably exposed to the toxicity of E-waste, thus putting themselves and their unborn infants at harm's way. Around 18 [9] million children and teenagers or beyond, starting at an early age of 5 years or so, are actively involved in the informal waste processing sector.

Adults and teenagers are more prone to be exposed to the toxic fumes and particulate matter through inhalation, corrosive agents and chemicals coming in contact with the skin and by consuming contaminated food and water which lead to a lot of health effects and cause damage to the metabolism.

Hence, an urgent and effective mandatory action is necessary to safeguard the millions of lives, especially children, teenagers and pregnant women, whose well-being is threatened by the informal management of E-waste.

\section{Natural Resources and Depletion Rate}

The natural resources are depleting at an alarming rate and its statistics is presented in Table 1 . The scarcity of metals from the earth's core will directly encourage secondary production through urban mining. A systematic process may be employed with a few stringent measures until the final products are put back into the supply chain, thus creating a sustainable circular economy [10].

Table 1. Depletion rate of natural resources due to virgin mining.

\begin{tabular}{ccccc}
\hline Precious Metal & $\begin{array}{c}\text { Quantity Available in } \\
\text { Below-Ground } \\
\text { Reserves (Tons) }\end{array}$ & $\begin{array}{c}\text { Annual Consumption } \\
\text { Rate (Tons) }\end{array}$ & $\begin{array}{c}\text { Depletion Period } \\
\text { (Years) }\end{array}$ & Major Regions of Source \\
\hline Gold & 50,000 & 4400 & 11 & $\begin{array}{c}\text { South Africa, USA, Indonesia } \\
\text { Peru, Australia, Poland } \\
\text { South Africa, Russia, }\end{array}$ \\
Pilver & 503,000 & 33,000 & 15 & 19 \\
Platinum & 69,000 & 252 & 31 & Zimbabwe \\
Copper & $870,000,000$ & $28,000,000$ & & Chile, Mexico, USA, Indonesia \\
\hline
\end{tabular}

There is an immediate need to monitor the quantity and flow of E-waste and to ensure that these monitoring developments are effective and achieved continuously, thus protecting the natural resources towards a sustainable society. 


\section{International Conventions, Regulations and Laws}

International policies and legislation regarding E-waste play a vital role as they set a degree of standards and commands to control the actions of stakeholders who are well connected with E-waste in government and private sectors [7]. This section will discuss the various laws that were enforced to mitigate the problems that rose with illegal practices on handling E-waste. The year 1992 witnessed The Basel Convention and its transboundary motion of hazardous waste and their disposal. The year 2015 witnessed the United Nations and all its member states endorsing the 2030 Agenda for Sustainable Development and assigning 17 Sustainable Development Goals (SDGs) and 169 [11] targets for eradication of poverty, protection of our planet, aiming for prosperity for all over a 15-year time period. The past few years have seen some improvements in the legal, institutional and infrastructural framework for achieving a legitimate management of E-waste in a few countries. Today, $71 \%$ of the global population has incorporated national and/or common policies [11].

\section{The Basel Convention}

The Basel Convention monitors the transboundary movements of hazardous and other wastes and obligates its parties to make sure that such wastes are handled appropriately and discarded in an environmentally sound manner [12]. With 175 [13] member countries in its support, its primary goal is to protect human health and the environment against the irreversible effects resulting from the generation, illegal transportation and management of hazardous and other wastes [13]. The EU was the first to enforce these laws in their member nations, but the USA has still not ratified the accord to date. With the Basel Ban in action, the transboundary movement of hazardous waste has curtailed to an extent, but this treaty has been unable to eradicate it completely and the illegal transportation of E-waste between developed and developing countries continues to take place [14-16].

\section{Achieving UN Sustainable Development Goals (SDGs) and E-Waste}

Rapidly escalating levels of E-waste and illegal and dangerous methods of treatment such as extraction of precious metals through incineration or open dumping in landfills pose a significant threat to the human health, environment and to the attainment of the SDGs.

E-waste management nearly correlate to most SDGs including:

- SDG 3: Good health and well-being,

- SDG 6: Clean waste and sanitation,

- SDG 8: Decent work and economic growth,

- SDG 11: Sustainable cities and communities

- SDG 12: Responsible consumption and production and

- $\quad$ SDG 14: Life below water

With the increase in demand for raw material towards the manufacturing of EEE, E-waste also nearly correlates to the SDG 12 [11] indicator focusing on the origin of raw material and on the domestic use of raw material.

A more precise SDG indicator for E-waste has been identified for tracking the growth in this waste stream and is of high concern due to its potential dangers and its high level of residuary value. It was added in the design plan for the 12.5.1 SDG indicator: National recycling rate and tons of material recycled. The prime need for involving E-waste is further elaborated in SDG indicator 12.4.2 [11]: Treatment of waste, generation of hazardous waste and hazardous waste management, by type of treatment. These targets and indicators are defined and measured with specific guidelines issued for monitoring purposes to ultimately achieve these goals in a 15-year span.

\section{E-Waste Legislations across the Globe}

Today, $71 \%$ of the population has incorporated policies on E-waste, different from region to region; the remaining $29 \%$ are yet to bind themselves with a legal framework to 
ensure legal practices for a sustainable E-waste management (Figure 3) [7]. Even with the countries that have enforced E-waste legislation, illegal practices and imports still exist.

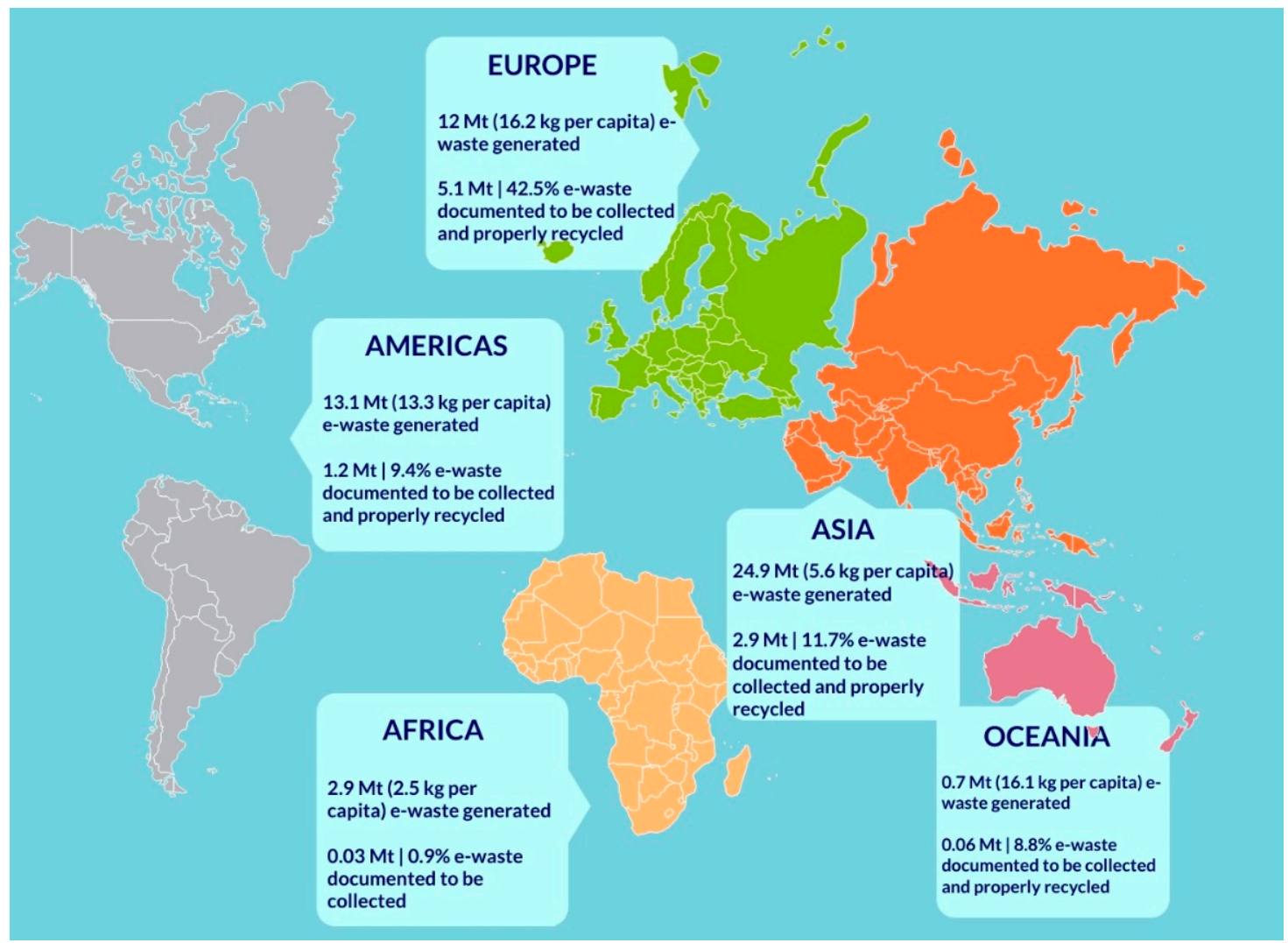

Figure 3. Current Statistics with E-waste documentation and formal recycling [7] (Source: Forti et al., 2020).

The existing policies and legislations of the top generators such as Asia, Africa, the Americas, Oceanian (inclusive of Australia and New Zealand) and the European Union (EU) countries are outlined briefly.

\subsection{Asia}

Domestic manufacturing and management of E-waste is influenced by a country's economic situation. China, for example, is Asia's and the World's largest producer of E-waste and an important destination for internationally generated E-waste (Table 2). For decades, the majority of Asian countries have struggled with the illicit import and processing of E-waste [17]. The need for effective E-waste management has been recognized throughout the South Asia area, with China, Japan, India, Korea and Singapore enacting legislation to govern E-waste management. The European Union's directives have served as a model for Asian countries creating E-waste legal frameworks [14]. Many regulations have been introduced pertaining to promotion of Circular Economy, EPR, PRO, RoHS Directives and permits and licenses for responsible handling of E-waste. 
Table 2. Major regions of E-waste generation [7] Source: Forti et al. (2020).

\begin{tabular}{cccc}
\hline Region & $\begin{array}{c}\text { Annual E-Waste } \\
\text { Generation (Mt) }\end{array}$ & $\begin{array}{c}\text { Percentage of E-Waste } \\
\text { Generation (\%) }\end{array}$ & E-Waste (kg/Person) \\
\hline Asia & 24.9 & 46.5 & 5.6 \\
The Americas & 13.1 & 24.4 & 13.3 \\
Europe & 12 & 22.4 & 16.2 \\
Africa & 2.9 & 5.4 & 2.5 \\
Oceania & 0.7 & 1.3 & 16.1 \\
\hline
\end{tabular}

\subsection{The Americas}

For decades, the Americas (the north and south continents) has been generating large amounts of E-waste (Table 2). The greatest producers of E-waste in the Americas are the higher-income areas, particularly the United States and Canada, followed by Brazil and Mexico [14]. Some states have enacted E-waste legislation, although there is a lack of consistency. Producer take-back restrictions and landfill prohibitions are in place in a few states. This has resulted in the majority of E-waste being sent to nations such as Mexico, China and Africa, where it is handled illegally, harming the environment. To address this issue, none of the states in the US have authority over international trade zones, making it impossible to ban export. As a result, E-waste export is regarded as permissible in the United States without federal legislation, which is still another incentive for policymakers to enact federal laws on E-waste management. The Resource Conservation and Recovery Act (RCRA), laws for recycling Cathode Ray Tubes (CRTs) and the National Strategy for Electronics Stewardship framework have all been used in the United States to manage domestic E-waste. In collaboration with original equipment manufacturers (OEMs) and retailers, the Environmental Protection Agency (EPA) of the United States has launched the Sustainable Materials Management (SMM) Electronics Challenge to collect unwanted electronics and recycle them through authorized recyclers [17,18].

In Latin America, regulatory progress takes time and just a few nations have passed E-waste legislation. Aside from Mexico, Costa Rica, Colombia and Peru, the region's main forces in ecologically sound E-waste treatment are now trying to improve the existing systems. Brazil and Chile laid the groundwork for the introduction of a formal E-waste regulatory framework in the year $2020[7,14]$.

\subsection{Europe}

In 1993, as soon as the Basel Treaty was signed, the EU Commission passed the Waste Shipment Regulation (WSR), thus resulting in the forbidding of exporting hazardous Ewaste to countries that are not members of the Organization for Economic Cooperation and Development (OECD) [19]. They introduced the Restriction of Hazardous Substances (RoHS) Directive (2012/95/EC) about a decade later [20]. This directive highlighted the use of environmentally friendly materials in product design and packaging to limit the usage of hazardous chemicals. It also attempted to raise the recycling rate of WEEE produced in the home.

The WEEE Directive (2012/19/EU) [21] regulates the bulk of E-waste in Europe in order to universally regulate E-waste management in its member countries. This directive is a comprehensive E-waste management regulation that governs the collecting, recycling and resource recovery processes. This underlines that collecting discarded EEE in a systematic and distinct manner will allow for higher recycling throughput, which will result in a larger turnover of useable E-waste fractions. Processed E-waste must also be accounted for and submitted to the National Enforcement Authority, according to the rule. The member states are required under the WEEE Directive to support the design and manufacture of EEEs that can be disassembled and recycled. The WEEE Directive establishes treatment technique requirements for various materials and components of E-waste, as well as storage locations, in order to ensure ecologically friendly processing. The directive also incorporates the 
extended producer responsibility (EPR) principle, which allows manufacturers to assume responsibility for recycling their end-of-life items [14,22].

\subsection{Africa}

Despite the fact that Africa produces around 5.4 percent of the world's E-waste, transboundary movements of WEEE are quite widespread in African countries. In Africa, as in most other continents, informal collectors and recyclers dominate E-waste management; there are neither established take-back systems nor licensing requirements for sorting and disassembling E-waste exist. The government's regulation over this industry is currently relatively limited and ineffective. In Africa, only a few nations have issued E-waste laws (for example, Egypt, Madagascar, Ghana, Rwanda, Nigeria, Cameroon, South Africa and Côte d'Ivoire). However, executing the law is tedious. Rwanda, for example, has recently established legislation controlling E-waste treatment. In 2012, Uganda enacted an Electronic Waste Management Policy. Rwanda, Tanzania, Burundi, Uganda, South Sudan and Kenya have formed a regional E-waste plan to develop a long-term E-waste management system in East Africa. Nonetheless, most African nations still lack appropriate E-waste legislation for an effective E-waste management [6].

\subsection{Oceania}

Australia, New Zealand and the Pacific Island sub-region make up the Oceania. Australia is the only country in the area to have enacted legislation specifically addressing E-waste management [23]. The Product Stewardship Act (2011), which was passed in Australia with the goal of recycling televisions and computers, has served as an example for other nations in the area in terms of enforcing producer duties in E-waste management. More than 291 [18] kt of TV and computer E-waste has been collected and recycled since the plan's commencement. Following Australia's lead, New Zealand and several other Pacific Island governments are implementing product stewardship frameworks. Many of the island nations in this region have broad environmental protection legislation that include waste management rules (including E-waste). Some of the Pacific's smaller countries are partnering with the EU to control hazardous waste [6].

Most countries' E-waste laws do not cover the entire extent of E-waste management and execution suffers as a result of the lack of a robust law enforcement network. Despite the fact that E-waste law affects $71 \%$ of the world's population, only $17.4 \%$ of all E-waste produced gets formally recycled (Figure 3) [10].

Despite the numerous laws and regulations in place, major regions are still dominated by the informal sector and continue to carry out illegal processes in E-waste management. Various reasons governing such illegal practices may be due to lack of strict enforcement of laws, awareness on the importance of transformation of the informal sector, lack of infrastructure and expertise, lack of knowledge on the best practices carried out globally, etc.

\section{Extended Producer Responsibility (EPR) and Producer Responsibility Schemes across the Globe}

Faced with exponentially rising waste levels, several governments examined their policy choices and determined that making the manufacturers responsible for the postconsumer phase of particular items would assist in evenly sharing responsibility among stakeholders. Manufacturers are required under the EPR policy to handle their end-of-life items in an ecologically responsible manner. Producers can take on either the financial obligation or the practical and organizational parts of the collection/recycling process through EPR programs. Producers can do so individually or collectively by enlisting the help of a third-party entity called producer responsibility schemes, which helps producers handle take-back and, in most cases, E-waste treatments as well (Rashmi and Seeram 2020).

The OECD has established four major kinds of EPR instruments, which are described below. 
1. Product take-back: This tool assigns responsibility for product end-of-life management to manufacturers or merchants. This is frequently accomplished by setting collecting and recycling goals for a product. Producers may choose to do an obligatory or voluntary takeback. Producers might also meet their goals by offering consumers incentives for returning unwanted products to a reputable merchant.

2. Economic and market-based instruments provide a monetary incentive for the implementation of EPR policies. They are available in four different forms:

- Deposit-refund: At the time of purchase, the buyer must pay a deposit, which is partially or totally recovered when the goods is returned to the producer/retailer at a defined location.

- $\quad$ Advanced disposal fees (ADF): Consumers are paid a price at the time of purchase for specific items depending on expected collection and treatment expenses. The charge is collected by either governmental or private bodies and used to fund the post-consumer treatment of the items in question. Consumers may be reimbursed for unused costs.

- Material tax: This is a tax paid on manufacturers who use virgin materials, difficult-to-recycle materials, or hazardous materials, in order to encourage them to use secondary (recycled) or less harmful resources. The tax should ideally be set at a level that covers the treatment expenses. Post-consumer items are collected, sorted and treated with the help of the tax.

- Upstream combination tax/subsidy (UCTS): This is a tax that is levied on manufacturers and then used to finance garbage treatment. It also offers businesses with incentives to change the design and materials of their products, as well as a finance plan to encourage recycling and treatment.

3. Regulations and performance standards imposed on producers can compel them to employ a minimum number of recycled materials, which can stimulate the return and recycling of end-of-life items. When combined with a fee, such rules can help to improve incentives for product redesign. The industries themselves might implement performance criteria that are either mandated or voluntary.

4. Information-based instruments are meant to raise public knowledge of EPR programs and thereby indirectly support them. Labeling items and components, communicating with customers about producer responsibility and waste separation and notifying recyclers about the materials used in products are all examples of possible measures [14,24-26] (Rashmi and Seeram 2020).

\section{Health Hazards and Environmental Impacts}

This section will go through the irreversible effects of E-waste processing in the informal sector on the environment and human health. EEEs are made up of a variety of components, the majority of which contain dangerous compounds that, if not handled appropriately, can harm human health and the environment [27]. It can have major consequences for individuals who live near facilities that recycle or burn E-waste (Table 3). 
Table 3. Health hazards and environmental impacts [4]. Source: (Grant, K.; 2013).

\begin{tabular}{|c|c|c|c|}
\hline E-Waste Component & $\begin{array}{l}\text { Process Followed by Informal } \\
\text { Sectors }\end{array}$ & Potential Health Hazard & $\begin{array}{l}\text { Potential } \\
\text { Environmental Impact }\end{array}$ \\
\hline Cathode Ray Tubes (CRT) & $\begin{array}{l}\text { Breaking of the copper yoke, removal } \\
\text { of copper yoke and openly discarding } \\
\text { it in landfills }\end{array}$ & $\begin{array}{l}\text { - } \\
\text { Milicosis commonly known as } \\
\text { - } \quad \text { Lacerations from CRT glass } \\
\text { Inhalation of phosphor } \\
\text { containing cadmium or other } \\
\text { metals, or skin contact with the } \\
\text { same }\end{array}$ & $\begin{array}{l}\text { Leaching of heavy metals } \\
\text { such as lead, barium and } \\
\text { others into groundwater, as } \\
\text { well as the release of toxic } \\
\text { phosphorus }\end{array}$ \\
\hline Printed Circuit Boards (PCBs) & $\begin{array}{l}\text { De-soldering and separating } \\
\text { computer chips }\end{array}$ & $\begin{array}{l}\text { - Inhalation of lead and tin } \\
\text { Inhaling potential brominated } \\
\text { dioxin, cadmium, mercury and } \\
\text { beryllium }\end{array}$ & $\begin{array}{l}\text { Probable emission of the exact } \\
\text { substances in to the } \\
\text { atmosphere }\end{array}$ \\
\hline Dismantled PCB Processing & Open incineration of PC boards & $\begin{array}{l}\text { Toxicity of tin, lead, brominated } \\
\text { dioxin, beryllium, cadmium and } \\
\text { mercury inhalation in employees and } \\
\text { nearby residents }\end{array}$ & $\begin{array}{l}\text { Brominated dioxins, } \\
\text { beryllium, cadmium and } \\
\text { mercury inhalation, as well as } \\
\text { tin and lead pollution of the } \\
\text { nearby environment, } \\
\text { including surface and } \\
\text { groundwater }\end{array}$ \\
\hline $\begin{array}{l}\text { Gold-Plated Substances and } \\
\text { other Chips }\end{array}$ & $\begin{array}{l}\text { Chemical stripping of contaminants } \\
\text { along riverbanks with nitric and } \\
\text { hydrochloric acid }\end{array}$ & $\begin{array}{l}\text { The eyes or skin coming in } \\
\text { contact with acid can cause } \\
\text { lifelong damage. } \\
\text { Inhalation of acid mists and } \\
\text { fumes, chlorine and sulfur } \\
\text { dioxide gases can cause } \\
\text { respiratory irritation and lead to } \\
\text { serious consequences such as } \\
\text { circulatory failure, pulmonary } \\
\text { edema and death. }\end{array}$ & $\begin{array}{l}\text { Direct release of } \\
\text { hydrocarbons, heavy } \\
\text { metals, brominated } \\
\text { chemicals and other } \\
\text { pollutants into the river } \\
\text { and its banks. } \\
\text { Acidification of the } \\
\text { river, which kills fish } \\
\text { and plants. }\end{array}$ \\
\hline $\begin{array}{l}\text { Plastics from the computer } \\
\text { and peripherals }\end{array}$ & $\begin{array}{l}\text { Lower temperature melting and } \\
\text { Shredding }\end{array}$ & $\begin{array}{l}\text { Workers living in the burning } \\
\text { operations vicinity may have been } \\
\text { exposed to hydrocarbons, brominated } \\
\text { dioxin and PAH. }\end{array}$ & $\begin{array}{l}\text { Brominated dioxins, heavy } \\
\text { metals and hydrocarbons } \\
\text { emissions in to the } \\
\text { atmosphere }\end{array}$ \\
\hline $\begin{array}{l}\text { Smelting of secondary steel, } \\
\text { copper and precious metals }\end{array}$ & $\begin{array}{l}\text { Steel or copper is recovered from } \\
\text { waste in the furnace. }\end{array}$ & $\begin{array}{l}\text { Dioxins and heavy metals may be } \\
\text { exposed to workers }\end{array}$ & $\begin{array}{l}\text { Dioxins and heavy metals are } \\
\text { released into the environment, } \\
\text { contaminating the air. }\end{array}$ \\
\hline Wires & $\begin{array}{l}\text { Open incineration for the recovery of } \\
\text { copper }\end{array}$ & $\begin{array}{l}\text { Workers living in the burning } \\
\text { operations vicinity may have been } \\
\text { exposed to brominated and } \\
\text { chlorinated dioxin and PAH }\end{array}$ & $\begin{array}{l}\text { Discharge of hydrocarbons } \\
\text { and ashes, including PAHs, } \\
\text { into the air, water and soil }\end{array}$ \\
\hline
\end{tabular}

Poor E-waste processing has far-reaching consequences that go beyond immediate human health [28]. They also include the indirect health consequences of ingesting food grown on E-waste-contaminated soil [29,30]. Illegal dump yards lead to groundwater contamination which in turn is put back into the food chain, thus giving rise to various diseases. Some metals disposed in the river bodies contaminate the potable properties of water [31]. Likewise, open incineration and acid leaching of E-waste exposes toxic fumes into the atmosphere leading to death or permanent damage of the respiratory organs of the workers engaged in this process or the surrounding residents [14,32,33]. Polluting the atmosphere can also cause serious effects such as damaging the ozone layer, global warming $[34,35]$. Heavy metal contamination in the soil causes a decrease of fertility in the topsoil, which then enters the food chain. Metal contamination can also cause genotoxicity, damaging the gene information, thus causing diseases such as cancer. The most susceptible population who are affected by illegal practices are children, pregnant women and workers in processing sites (Figure 4). 


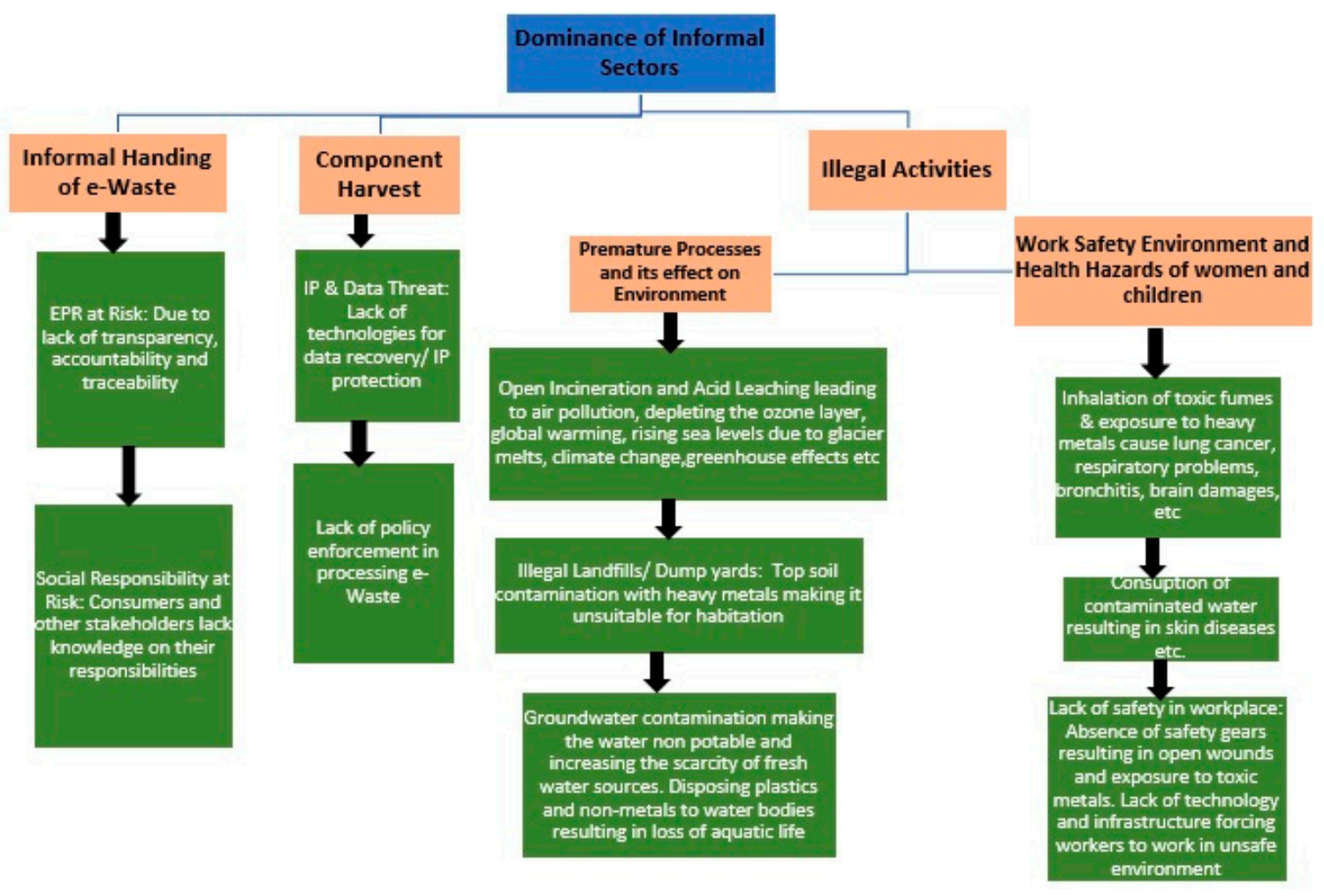

Figure 4. Hazards leading to the dominance of the informal sector.

The illegal activities continue to be practiced in both developing as well as developed countries for a variety of reasons (Figure 4), including but not limited to

- cheap labor,

- illiteracy rate,

- lack of policy enforcement,

- lack of statistics on the amount of E-waste generated,

- lack of formal infrastructure,

- lack of awareness among stakeholders,

- inadequate individual and social responsibilities,

- dominance of informal sector.

\section{Urban Mining V/S Virgin Mining}

Virgin mining has resulted in environmental catastrophic events in the past and continues to threaten the sustainability process of the environment. The earth's core is being upset due to the mining actions, resulting in natural disasters and the loss of life and habitat. Global warming is increasing at a disturbing speed, terrorizing the globe with extinction. In order to overcome the dangers created by man, it is time to innovate and design sustainable methods to utilize the existing natural resources. The majority of the EEE products contain precious metals and base metals, and some have rare earth metals and other resources to achieve innovative ICT and IT revolution. What if we can recycle and recover them and put them back into the supply chain as a secondary raw material without causing harm to the environment and human health? It is possible through a concept known as urban mining or above the ground mining.

The processing of WEEE can be complex and will have to deal with various lethal toxic substances. However, it is not impossible if there is collective thinking for a common global benchmark technology and infrastructure facilities across the globe. Urban mining is the new trend in the normal processing of E-waste and carrying it out in a formal system is very essential to achieve a sustainable and circular economy [36]. 
The following figures give an overview on the global demand and supply through virgin and urban mining of precious and PGM metals (Figures 5-8). It is observed that the supply of gold from virgin mining and recycling for the past 10 years have almost met the demand every year (Figure 5). However, in the last 4 years, there has been a decline in the demand and yet virgin mining has been a continuous process. It is undeniable that virgin mining meets the bulk of demand, but it is time to consider the price we pay to fulfil this demand and if it is worthwhile. On the other hand, recovery through benchmark best technology practices will not only fetch the finest form of valuables, but will also help maintain the eco system and natural resources from being scarce [37-39].

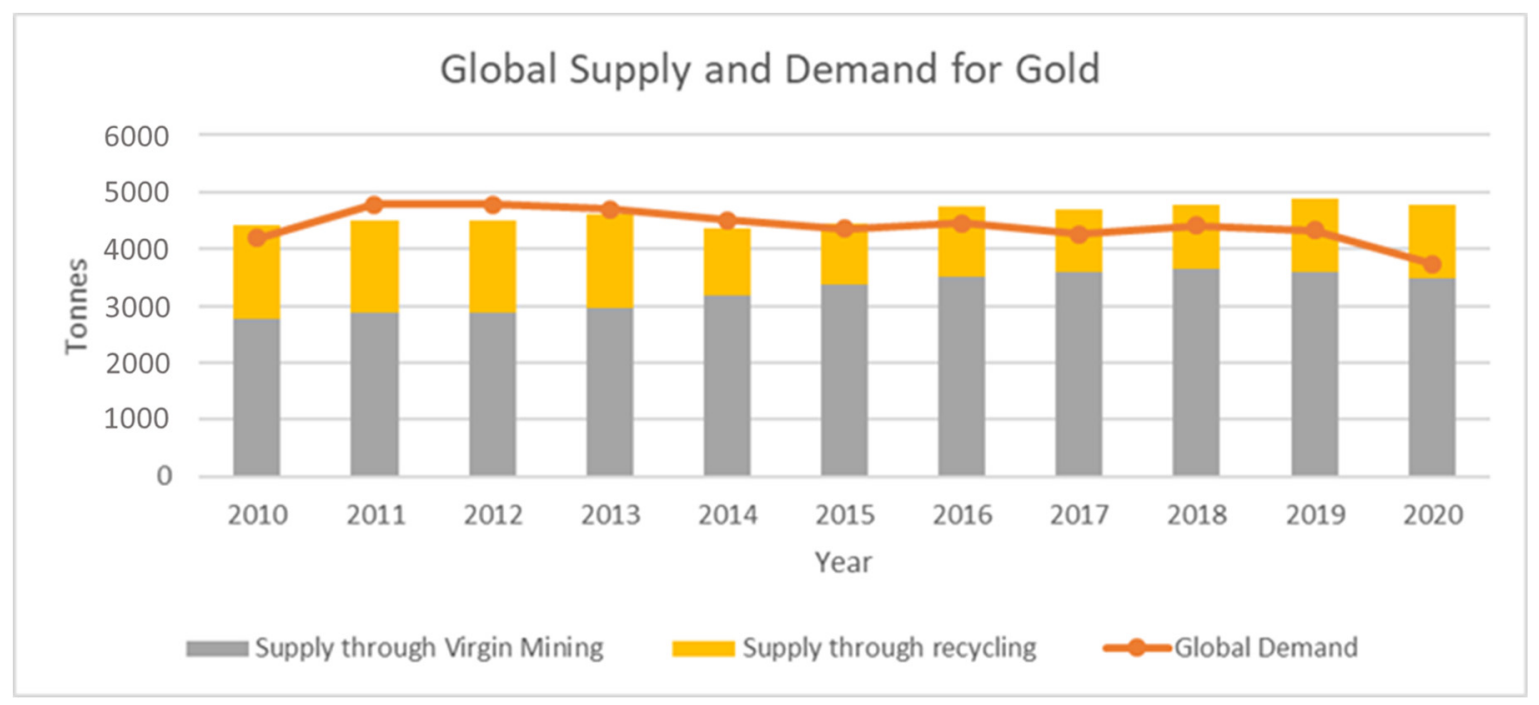

Figure 5. Trend in the global gold demand and supply from 2010-2020 (Source: World Gold Council 2020).

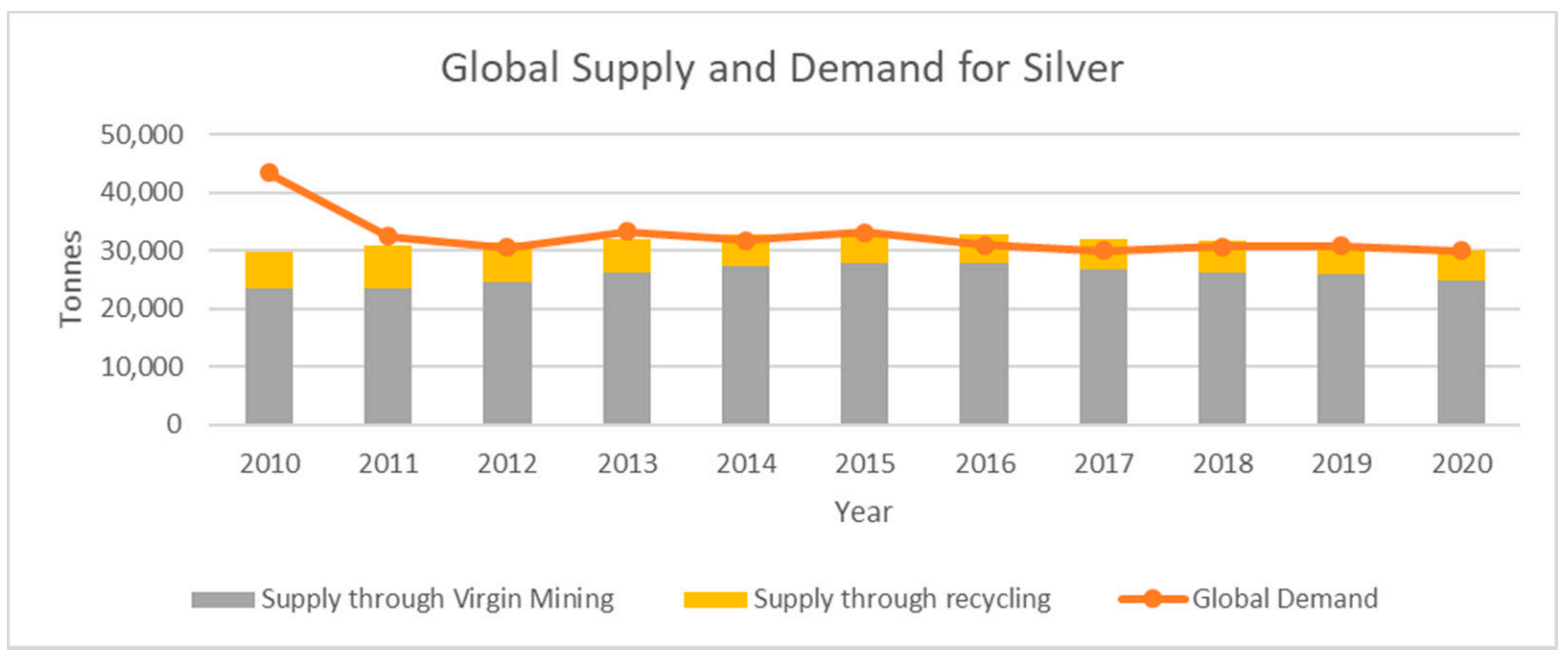

Figure 6. Trend in the global silver demand and supply from 2010-2020 (source: The Silver Institute: World Silver Survey 2020). 


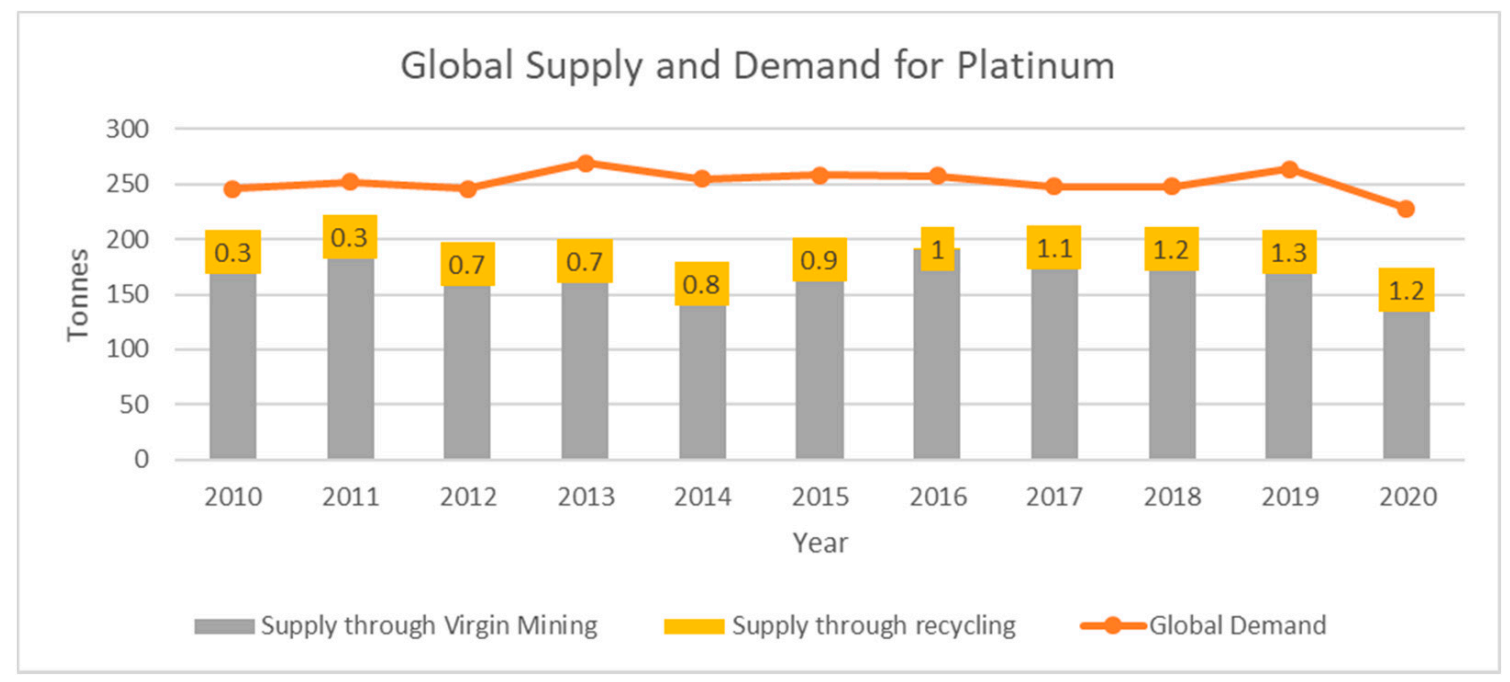

Figure 7. Trend in the global platinum demand and supply from 2010-2020 (source: John Matthey Reports 2020).

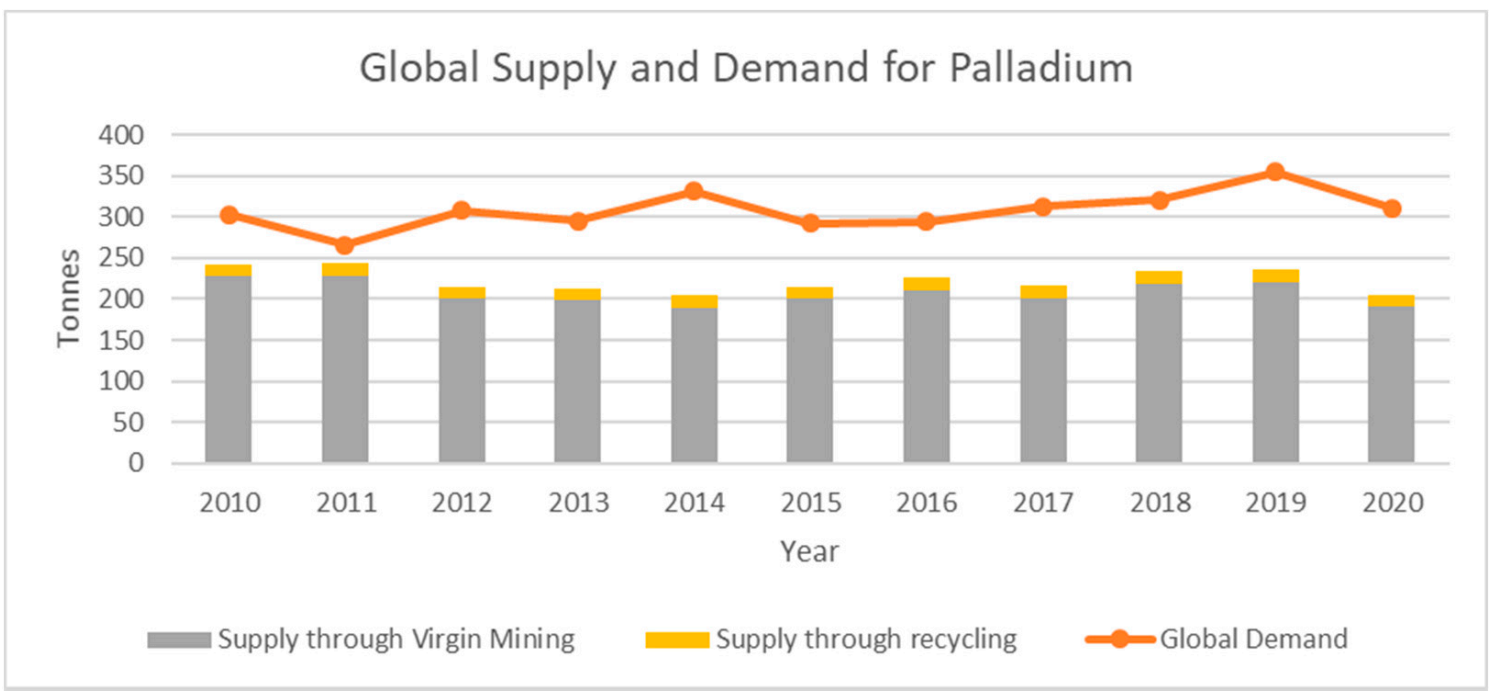

Figure 8. Trend in the global palladium demand and supply from 2010-2020 (source: John Matthey Reports 2020).

Similarly, the demand for silver has been met for several years now, but the mining still continues, thus deteriorating the environment (Figure 6). Nevertheless, global supply for both platinum and palladium have not met the demand so far (Figures 7 and 8). Several endangered rare earth metals and strategic elements are utilized in defense equipment such as guidance and control systems, targeting and weapon systems, electronic warfare, communication systems and electric motors and may all be recovered in a systematic procedure [40-42] (Figure 9). 


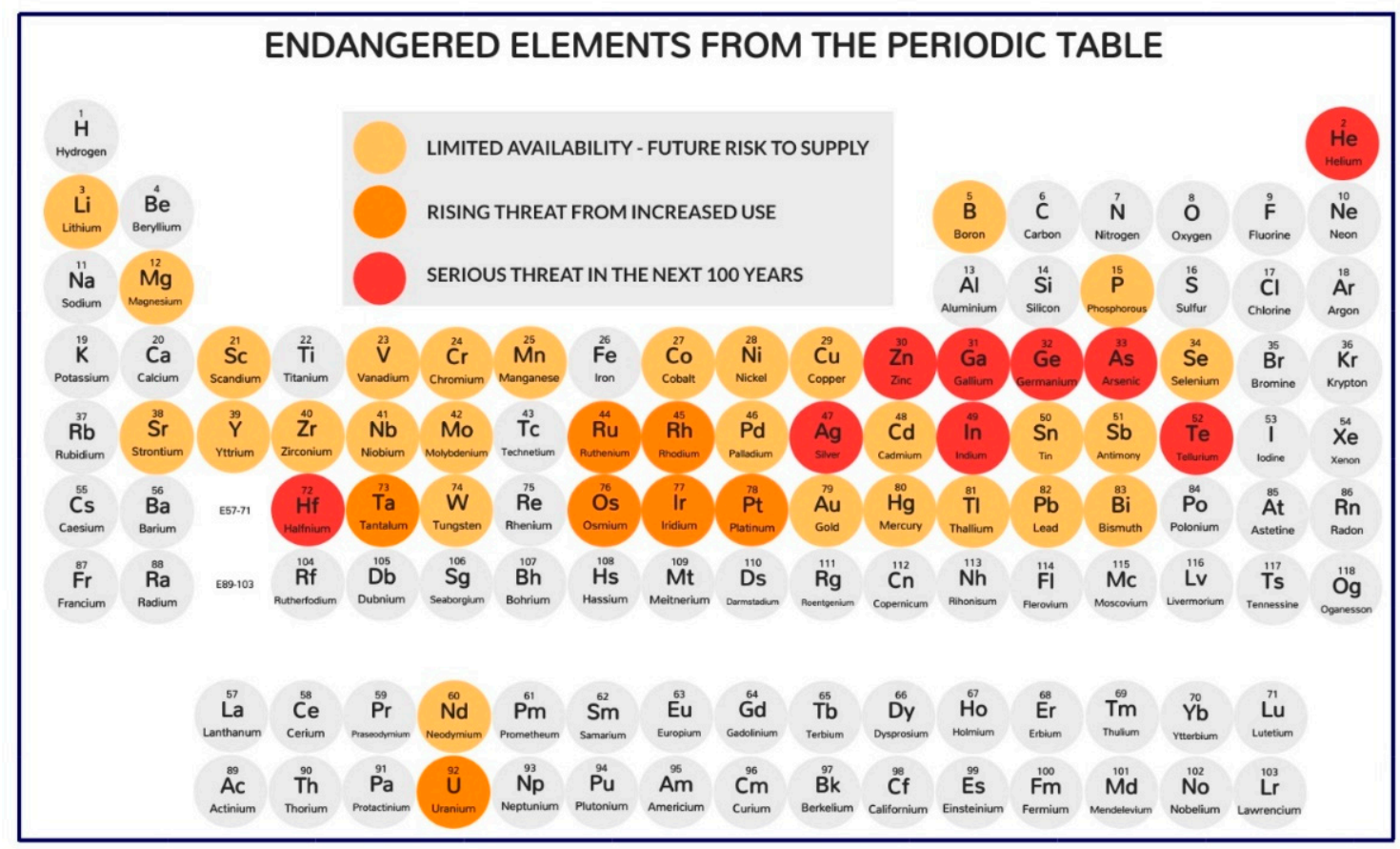

Figure 9. The endangered metals in the periodic table (source: ACS Green Chemistry Institute).

To sum up, despite the fact that only $17.4 \%$ of E-waste generated globally is being processed in formal sectors, over $15 \%$ of demand is satisfied in practically all valuable metals. Visualizing a future where $100 \%$ of E-waste being processed formally, we would achieve around $85-95 \%$ of the demand or more. Virgin mining should not be considered as an option in order to achieve a sustainable and decarbonized environment [43].

\section{Entrepreneurship and Expertise}

E-waste market is increasing rapidly and there is a need for entrepreneurs to identify the business opportunities and make a change by setting up formal recycling plants.

Formal capacity is one of the key shortcomings in E-waste management. Only 25-35 percent of global E-waste creation can be handled by existing formal infrastructure; the rest must be landfilled or accumulated informally [44-46]. This gives the informal sector an extra incentive to continue dominating the E-waste system.

To get started and to sustain on the entrepreneurial campus, one needs a lot of knowledge, experience and skills. Being able to identify the right technologies and implement the global best practices is also a major requirement in the formal run.

The industrial and institutional collaborations may help innovate state-of-the-art indigenous technologies in home ground instead of technology imports. This helps enhance the interest of the new entrants and also reduces the current practice of investing on foreign technologies.

The establishment of R\&D sectors to develop newer ideas for dealing with E-waste will assist young people in identifying professions in the field of E-waste management. Many major developing nations are providing incentives or financial support tools to promote E-waste management enterprises at various levels. Hence, the same should be implemented in the developing nations to revamp the environment and resources from the depletion [22,47].

It is imperative for the future generation to learn and act responsibly towards E-waste management. This accounts for knowledge transfer at a young age through awareness programs and educational activities [48]. Varieties of stakeholders such as consumers, OEMs, recycling partners, corporate sectors, government sectors, academicians, NGO representatives and bulk consumer generators are to be included in the process of knowledge transfer to facilitate for a holistic approach of environmentally sound E-waste management. 
Instead of burdening each sector, one must consider this as a social responsibility to create a green and healthy atmosphere to extend the life of our planet Earth.

\section{Discussion on the Global Challenges and Opportunities in a Structured E-Waste Management}

Despite the fact that E-waste and EPR legislation is in place in two-thirds of the globe, only more-or-less $20 \%$ of E-waste gets recycled legally. Citing the statistics and current practices outlined above, the following gaps have been identified and analyzed for solutions.

1. Legal Framework: The gaps and solutions with respect to the current policies are explained below.

Though the characteristics of E-waste generated is common across the globe, different countries have different regulations. Thus, mapping a common legal framework and enforcing it across the globe will avoid confusion and conflicts of interest with respect to policies.

Though the natural resources used for manufacturing the products are same and the value of metals is same for both urban and virgin mining, traditional practices of virgin mining are continued to date. Enforcing laws to regulate urban mining and creating awareness of a closed loop economy mineral reserves thus contributes to a sustainable and greener environment. Urban mining has tremendous benefits, such as but not limited to:

- Cheaper than virgin mining,

- More sustainable and effective,

- Help preserve natural resources,

- No harm to the environment as it takes place in a controlled system,

- Health and safety of women and children are protected,

- Helps achieve a decarbonized circular economy.

Developing countries must follow global best practices carried out globally rather than inducing laws according to their choices. Stakeholders must be aware of the permits and licensures required to set up formal processing plants. Implementation of a common mandatory permits and licenses globally would add more value to the formal system of Ewaste management. A good example would be the best practices carried out in developed nations such as the EU where common law is being followed by the EU countries for effective E-waste management. This helps the stakeholders to have sound knowledge on their roles and responsibilities and, thus, contribute towards an environmentally sound E-waste management.

2. Benchmark Technology: Although E-waste legislation is the main path for the transition towards a circular economy, state of the art infrastructure and benchmark technologies also play an important role. The resources, hazards and impacts for E-waste generated are the same across the globe, but each country has a different processing system. There is an immediate need for the international leaders to review the global best technological practices carried out to arrive at a benchmark technology for each of the processing cycles of E-waste [49-51]. Innovation may be the key to come up with indigenous technology for recycling, re-use, repair, refurbishment and component harvesting to extend the life spans of the products and components and to optimize and increase the outputs of E-waste processing plants. This would also help us achieve transparency and avoid illegal methods of handling E-waste.

3. Implementation of EPR: Even when the chemistry of the product remains the same and producers use the same resources, the EPR policy differs greatly between OECD and non-OECD countries, thus creating complex issues in E-waste management. Stakeholders are not aware of the roles and responsibilities because of the confusion in policies varying across the globe. To establish a legal and environment-friendly sound management of E-waste, stringent adoption of a mandated universal EPR law across the globe is critical. Implementation of a common law will make sure gener- 
ators and manufacturers are aware of their responsibilities and will act accordingly without conflicts.

4. Green policies such as Green Product Identification should be enforced mandatorily, where the producers are responsible for identifying the chemistry of their product and making sure that each component manufactured can be harvested at their end-oflife. Clearly, enforcement of EPR is very essential in order to drive the stakeholders towards responsible design of products, production and processing of the recycled E-waste. Such practices can only be fruitful when the government supports and encourages the formal system of E-waste management by facilitating their needs through financial, technological or expert support.

5. Consumer Behavior: While manufacturers and generators need to act responsibly, there is a need for consumers to also play a role in disposing their E-waste responsibly. Regulating the manufacturers to give comprehensive information about each product to the consumers containing information about the composition, hazards of improper disposal, practices of re-use, repair and refurbishment, life span of the product, etc., can bring a significant change in the way consumers view their contributions to a greener environment. In addition, awareness activities need to be conducted for consumers on the effects of illegal dumping of E-waste.

6. Transformation of the Informal Sector: Unsustainable methods of handling E-waste have created a problem the size of a planet. Women and children from the illiterate sections of society are used for dismantling E-waste. Processes such as manual stripping of cables, lack of safety gear, open incineration and acid leaching have led to various diseases and caused irreparable damage to the environment. Due to a significant dominance of the informal sector handling E-waste (Figure 4), it is a grave task to educate and transform them about the hazards caused due to their illegal and unorthodox methods of processing the E-waste. Formalizing them would solve $90 \%$ of the problems caused to the environment by E-waste and would be easy to trace and maintain transparency on the amount of E-waste generated and processed.

\section{Conclusions}

In conclusion, after the agricultural revolution and IT revolution, now, E-waste is creating a revolution with its unsustainable methods of processing. The planet is deteriorating because of the harm caused by human beings. Practices such as illegal dumping of waste, virgin mining, plasticizing the ocean have disturbed the earth's core, causing an imbalance in nature. Developed nations continue to grow, but the developing nations are struggling due to lack of expertise, infrastructure and funds, etc. It is imperative for all to consider the E-waste problem as a shared responsibility for protecting the planet and the safety and health of all, especially children, teenagers and women.

There is a need to create and enforce mandatory global best practices in the developing nations. A common global approach towards legal framework, EPR, benchmark technologies, licenses or permissions and transformation of informal sector is the first and foremost step towards a sustainable future. A holistic approach of enforcing a common legal framework will ensure strong awareness among all stakeholders, including consumers on their behavioral pattern with E-waste. The policymakers and the major contributors responsible for creating a benchmark technology should focus on the best practices carried out globally and enforce one common technology for both developed and developing nations, irrespective of their current practices. It is highly essential for the policymakers to enforce a common EPR policy irrespective of their choices and this must be implemented mandatorily. Keeping in mind the global demand for precious metals and the amount of recovery from appropriate treatment of WEEE, it is important to mandate the transparency of E-waste collection to maximize formal system of collection and treatment, thus promoting urban mining. It is most important to educate and create awareness among the consumers and the youth for better and innovative thinking of handing E-waste. Transformation of the informal sector is the need of the hour to achieve a structured process of E-waste 
management. Lastly, regulating urban mining compulsorily will help balance nature. It is time to go back to our roots and follow the path of circularity to protect our planet and preserve the natural resources.

Author Contributions: Conceptualization, V.M. and S.R.; Data curation, V.M. and S.R.; Formal analysis, V.M.; Funding acquisition, V.M. and S.R.; Investigation, V.M. and S.R.; Methodology, V.M. and S.R.; Project administration, V.M. and S.R.; Resources, V.M.; Software, V.M.; Visualization, V.M.; Writing-original draft, V.M. and S.R.; Writing—review \& editing, V.M. and S.R. All authors have read and agreed to the published version of the manuscript.

Funding: This research received no external funding.

Institutional Review Board Statement: Not applicable.

Informed Consent Statement: Not applicable.

Conflicts of Interest: The authors declare no conflict of interest.

\section{References}

1. WEEE Forum. Report on International E-Waste Day 2021. Available online: https://weee-forum.org/iewd-about/ (accessed on 25 October 2021).

2. Kumar, A.; Holuszko, M.; Espinosab, D.C.R. E-waste: An overview on generation, collection, legislation and recycling practices. Resour. Conserv. Recycl. 2017, 122, 32-42. [CrossRef]

3. Grant, K.; Goldizen, F.C.; Sly, P.D.; Brune, M.-N.; Neira, M.; Berg, M.V.D.; Norman, R. Health consequences of exposure to E-waste: A systematic review. Lancet Glob. Heath 2013, 1, e350-e361. [CrossRef]

4. Mihai, F.-C.; Gnoni, M.-G.; Meidiana, C.; Ezeah, C.; Elia, V. Chapter 1-Waste Electrical and Electronic Equipment (WEEE): Flows, Quantities, and Management-A Global Scenario. In Electronic Waste Management and Treatment Technology; Prasad, M.N.V., Vithanage, M., Eds.; Butterworth-Heinemann: Kidlington, UK, 2019; pp. 1-34.

5. United Nations Children's Fund (UNICEF). Policy 2020: Protection of Children during the COVID-19 Pandemic. Available online: https: / / www.unicef.org/documents / protection-children-during-covid-19-pandemic-children-and-alternative-care (accessed on 25 October 2021).

6. The United Nations Global E-Waste Monitor-2020, a Collaborative Product of Global E-Waste Statistics Partnership (GESP), the International Telecommunication Union (ITU), and the International Solid Waste Association (ISWA). Available online: http:/ / E-wastemonitor.info/ (accessed on 26 October 2021).

7. Baldé, C.P.; van den Brink, S.; Forti, V.; van der Schalk, A.; Hopstaken, F. The Dutch WEEE Flows 2020. “What happened between 2010 and 2018"; United Nations University (UNU)/United Nations Institute for Training and Research (UNITAR): Tokyo, Japan, 2020.

8. Perkins, D.N.; Drisse, M.B.; Nxele, T.; Sly, P.D. E-waste: A global hazard. Ann. Glob. Health 2014, 80, 286-295. [CrossRef] [PubMed]

9. The World Health Organization (WHO) Report 2021: Children and Digital Dumpsites. Available online: https://www.who.int/ publications-detail-redirect/9789240023901 (accessed on 28 October 2021).

10. Secretariat of the UN Environment Management Group (EMG). "A New Circular Vision for Electronics: Time for a Global Reboot". Geneva, Switzerland: World Economic Forum (WEF). 2019. Available online: https://www3.weforum.org/docs/WEF_ A_New_Circular_Vision_for_Electronics.pdf (accessed on 29 October 2021).

11. UN Sustainable Development Agenda 2021: Sustainable Development Goals (SDGs). Available online: https://www.in.undp. org/content/india/en/home/sustainable-development-goals.html (accessed on 28 October 2021).

12. Hackett, D.P. Assessment of the Basel Convention on the control of Transboundary Movements of Hazardous Wastes and Their Disposal. Am. Univ. J. Int. Law Pol. 1989, 5, 31.

13. United Nations Environment Programme (UNEP). Report on the Basel Convention on the Control of Transboundary Movements of Hazardous Wastes. Available online: http:/ / www.basel.int/TheConvention/Overview/tabid/1271/Default.aspx (accessed on 26 October 2021).

14. Patil, R.A.; Ramakrishna, S. A comprehensive analysis of e-waste legislation worldwide. Environ. Sci. Pollut. Res. 2020, 27, 14412-14431. [CrossRef]

15. E-Waste. Available online: https://www.sprep.org/pacwaste/E-waste (accessed on 30 October 2021).

16. E-Waste Country Assessments. Available online: www.sprep.org/attachments/Publications/WMPC/Summary_Rep_PacWaste_ TAP_E-waste_Country_Assess.pdf (accessed on 25 October 2021).

17. Alghazo, J.; Ouda, O.; Elhassan, A. E-waste environmental and information security threat: GCC countries vulnerabilities. Euro-Mediterr. J. Environ. Integr. 2018, 3, 5-9. [CrossRef]

18. Baldé, C.P.; Forti, V.; Gray, V.; Kuehr, R.; Stegmann, P. “The Global E-Waste Monitor 2017”. Edited by United Nations University (UNU), International Telecommunication Union (ITU), and International Solid Waste Association (ISWA). 2017. Available online: https:/ / collections.unu.edu/eserv/UNU:6341/Global-E-waste_Monitor_2017_electronic_single_pages_pdf (accessed on 29 October 2021).

19. Jupille, J. The European Union and international outcomes. Int. Organ. 1999, 53, 409-425. [CrossRef] 
20. European Commission (2012/95/EU). Restriction of Hazardous Substances in Electrical and Electronic Equipment (RoHS). Available online: https:/ / ec.europa.eu/environment/topics/waste-and-recycling/rohs-directive_en (accessed on 29 October 2021).

21. European Community Directive 2012/19/EU. Waste Electrical and Electronic Equipment Directive (WEEE Directive). Available online: https://eur-lex.europa.eu/legal-content/EN/TXT/PDF/?uri=CELEX:32012L0019\&from=EN (accessed on 29 October 2021).

22. Cucchiella, F.; D'Adamo, I.; Koh, S.L.; Rosa, P. A profitability assessment of European recycling processes treating printed circuit boards from waste electrical and electronic equipments. Renew. Sustain. Energy Rev. 2016, 64, 749-760. [CrossRef]

23. Patil, R.A.; Ramakrishna, S. A Comprehensive Analysis of E-Waste Legislation Worldwide; Springer: Berlin, Germany, 2020; pp. 5-10.

24. Zeng, X.; Yang, C.; Chaing, J.F.; Li, J. Innovating E-waste management: From macroscopic to microscopic scales. Sci. Total Environ. 2017, 575, 1-5. [CrossRef]

25. Zhang, L.; Yuan, Z.; Bi, J.; Huang, L. Estimating future generation of obsolete household appliances in China. Waste Manag. Res. 2012, 30, 1160-1168. [CrossRef]

26. Krumay, B. Chapter Privacy Technologies and Policy. In The E-Waste-Privacy Challenge: A Grounded Theory Approach; Series Lecture Notes in Computer Science (LNCS); Springer: Wien, Austria, 2016; pp. 48-68.

27. Arain, A.; Neitzel, R.L. A Review of Biomarkers Used for Assessing Human Exposure to Metals from E-waste. Int. J. Environ. Res. Publ. Health 2019, 16, 15-16. [CrossRef] [PubMed]

28. Roychowdhury, P.; Alghazo, J.M.; Debnath, B.; Chatterjee, S.; Ouda, O.K.M. Security threat analysis and prevention techniques in electronic waste. In Waste Management and Resource Efficiency; Springer: Singapore, 2018. [CrossRef]

29. Sankhla, M.S.; Nandan, M.; Mohril, S.; Singh, G.P.; Chaturvedi, B.; Kumar, R.; Kumari, M. Effect of Electronic waste on Environmental \& Human health-A Review. IOSR J. Environ. Sci. Toxicol. Food Technol. 2016, 10, 98-104.

30. Tiller, K. Heavy Metals in Soils and Their Environmental Significance. In Advances in Soil Science; Springer: Berlin/Heidelberg, Germany, 1989; pp. 113-142.

31. Pinto, V.N. E-waste hazard: The impending challenge. Indian J. Occup. Environ. Med. 2008, 12, 65-70. [CrossRef]

32. Ramesh Babu, B.; Parande, A.K.; Ahmed Basha, C. Electrical and electronic waste: A global environmental problem. Waste Manag. Res. 2007, 25, 307-318. [CrossRef]

33. Kiddee, P.; Naidu, R.; Wong, M.H.; Hearn, L.; Müller, J.F. Field investigation of the quality of fresh and aged leachates from selected landfills receiving E-waste in an arid climate. Waste Manag. 2014, 34, 2292-2304. [CrossRef] [PubMed]

34. Gangwar, C.; Choudhari, R.; Chauhan, A.; Kumar, A.; Singh, A.; Tripathi, A. Assessment of air pollution caused by illegal E-waste burning to evaluate the human health risk. Environ. Int. 2019, 125, 191-199. [CrossRef] [PubMed]

35. Rautela, R.; Arya, S.; Vishwakarma, S.; Lee, J.; Kim, K.-H.; Kumar, S. E-waste management and its effects on the environment and human health. Sci. Total Environ. 2021, 773, 145623. [CrossRef] [PubMed]

36. Ramanayaka, S.; Keerthanan, S.; Vithanage, M. Urban Mining of E-Waste: Treasure Hunting for Precious Nanometals. In Handbook of Electronic Waste Management; Prasad, M.N.V., Vithanage, M., Borthakur, A., Eds.; Butterworth-Heinemann: Kidlington, UK, 2019; pp. 19-54.

37. Ahirwar, R.; Tripathi, A.K. E-waste management: A review of recycling process, environmental and occupational health hazards and potential solutions. Environ. Nanotechnol. Monit. Manag. 2021, 15, 100409. [CrossRef]

38. Kiddee, P.; Naidu, R.; Wong, M.H. Electronic waste management approaches: An overview. Waste Manag. 2013, 33, 1237-1250. [CrossRef] [PubMed]

39. Step: Solving the E-Waste Problem. Available online: https://www.step-initiative.org/organisation-rev.html (accessed on 30 October 2021)

40. Chatterjee, A.; Abraham, J. Efficient management of E-wastes. Int. J. Environ. Sci. Technol. 2016, 14, 211-222. [CrossRef]

41. Harikrushnan, B.; Shreyass, G.; Hemant, G.; Pandimadevi, M. Recovery of metals from printed circuit boards(pcbs) using a combination of hydrometallurgical and biometallurgical processes. Int. J. Environ. Res. 2016, 10, 511-518.

42. Pant, D.; Joshi, D.; Upreti, M.K.; Kotnala, R.K. Chemical and biological extraction of metals present in E waste: A hybridtechnology. Waste Manag. 2012, 32, 979-990. [CrossRef]

43. Shagun, K.A.; Arora, A. Proposed Solution of E-waste Management. Int. J. Future Comput. Commun. $2013,2,490-493$.

44. Lundgren, K. The Global Impact of E-Waste: Addressing the Challenge; International Labour Organization: Geneva, Switzerland, 2012.

45. Rene, E.R.; Sethurajan, M.; Ponnusamy, V.K.; Kumar, G.; Dung, T.N.B.; Brindhadevi, K.; Pugazhendhi, A. Electronic waste generation, recycling and resource recovery: Technological perspectives and trends. J. Hazard. Mater. 2021, 416, 125664. [CrossRef] [PubMed]

46. Tanskanen, P. Management and recycling of electronic waste. Acta Mater. 2013, 61, 1001-1011. [CrossRef]

47. Kaya, M. Recovery of metals and nonmetals from electronic waste by physical and chemical recycling processes. Waste Manag. 2016, 57, 64-90. [CrossRef] [PubMed]

48. Hazardous Waste Including E-Waste. Available online: https://www.epa.govt.nz/industry-areas/hazardous-substances/ hazardous-waste/hazardous-waste-types / (accessed on 26 October 2021).

49. Islam, A.; Ahmed, T.; Awual, M.R.; Rahman, A.; Sultana, M.; Aziz, A.A.; Monir, M.U.; Teo, S.H.; Hasan, M. Advances insustainable approaches to recover metals from E-waste-A review. J. Clean. Prod. 2020, 244, 118815. [CrossRef]

50. Hong, J.; Shi, W.; Wang, Y.; Chen, W.; Li, X. Life cycle assessment of electronic waste treatment. Waste Manag. 2015, 38, 357-365. [CrossRef] [PubMed] 
51. Xue, M.; Xu, Z. Application of life cycle assessment on electronic waste management: A review. Environ. Manag. 2017, 59, 693-707. [CrossRef] 